\title{
The Occurrence and Location of Teichoic Acids in Lactobacilli
}

\author{
By J. BADDILEY AND A. L. DAVISON \\ Department of Chemistry, King's College, University of Durham, Nerwcastle upon Tyne
}

(Received 2 September 1960)

\begin{abstract}
SUMMARY
The walls and cell contents of a number of lactobacilli were prepared by mechanical disruption of the organisms followed by differential centrifugation. The nature of the teichoic acid present in the separated fractions was determined by extracting it with dilute trichloroacetic acid, precipitating with ethanol and identifying the precipitated polymer by hydrolysis to ribitol or glycerol phosphates and other recognizable degradation products. All the organisms contained a glycerol teichoic acid within the cell. This and similar observations with other bacteria indicates that glycerol teichoic acids play an important part in cellular metabolism. Both glycerol and ribitol teichoic acids occur in walls. The presence and type of teichoic acid in the walls correlate with the serological behaviour of lactobacilli and provide a useful means of classification. It is suggested that teichoic acids themselves may possess antigenic properties.
\end{abstract}

\section{INTRODUCTION}

The teichoic acids were first obtained from bacteria by extraction from whole defatted organisms with cold dilute trichloroacetic acid, followed by precipitation with ethanol (Armstrong, Baddiley, Buchanan, Carss \& Greenberg, 1958). These preparations were mixtures containing the two types of this group of compounds: the glycerol teichoic acids are polymers of glycerophosphate bearing D-alanine residues in ester linkage with hydroxyl groups in the polymer, whereas the ribitol teichoic acids are similar polymers of ribitol phosphate bearing both $\mathrm{D}$-alanine residues and sugars. The number and nature of the sugar residues and the configuration of the glycosidic linkages varies in the ribitol compounds from different organisms. Most of the structural details of the ribitol teichoic acid from Bacillus subtilis have now been determined (Armstrong, Baddiley \& Buchanan, 1960).

Purified walls of Bacillus subtilis, Lactobacillus arabinosus 17-5, and Staphylococcus aureus $\mathbf{H}$ contain large amounts $(40-60 \%$ of their dry weight) of the appropriate ribitol teichoic acid but no glycerol teichoic acid, and it was concluded that the glycerol derivatives in material from whole organisms came from the cell contents. A more detailed survey of the presence of both types and their location in Lactobacillus was undertaken in an effort to understand their function and possible relationship to biochemical or serological properties of bacteria. 


\section{METHODS}

Organisms. Most of the organisms studied were obtained originally from the National Collection of Industrial Bacteria (NCIB) and their identity was checked before use by physiological and biochemical tests. According to Sharpe (1957) Lactobacillus plantarum NCIB 3254 is $L$. casei in serological group B and $L$. bulgaricus NCIB 76 is $L$. casei var. rhamnosus serological group C. L. delbrueckii NCIB 8608 has not been classified serologically but it is a strain of $L$. casei var. rhamnosus very closely related to the NCIB 76 strain, and almost certainly belongs to serological group $\mathbf{C}$.

Conditions for growth. Organisms were grown in batch culture (9 or 15 1.) in a liquid medium of the following composition: tryptone (Oxoid) 20 g.; yeast extract (Oxoid) 10 g.; sodium acetate 10 g.; glucose 20 g.; $\mathrm{KH}_{2} \mathrm{PO}_{4} 4.5 \mathrm{~g}$.; $\mathrm{NaOH} \mathrm{1.04}$ g.; inorganic salts B (Barton-Wright, 1946) $5 \mathrm{ml}$.; oleic acid $0.01 \mathrm{ml}$.; Tween $4.01 \mathrm{ml}$.; L-histidine hydrochloride $100 \mathrm{mg}$; d distilled water $1000 \mathrm{ml}$.

Oleic acid was added for Lactobacillus bulgaricus, $L$. delbrueckii, L. helveticus and L. lactis, and L-histidine hydrochloride was added for rapid growth of $L$. delbrueckii (Ikawa \& Snell, 1960). L. bulgaricus, L. casei var. rhamnosus (3 strains), L. delbrueckii, L. fermenti, $L$. helveticus and $L$. lactis were grown at $37^{\circ}$ for $16 \mathrm{hr}$; $L$. plantarum and $L$. casei at $30^{\circ}$ for $16 \mathrm{hr}$; L. brevis and L. buchneri at $30^{\circ}$ for $45-$ $48 \mathrm{hr}$.

Preparation of cell walls. Organisms were harvested in a refrigerated Sharples centrifuge, washed with cold physiological saline and suspended in cold distilled water (about $20 \mathrm{~g}$. wet weight organism/100 ml. water). Disruption was carried out with a Mickle vibrator (Salton \& Horne, 1951) and walls were collected by centrifugation. After washing and centrifuging several times with $\mathrm{m}$-phosphate buffer ( $\mathrm{pH} 7$ ) and distilled water to remove traces of cytoplasmic material and whole organisms, the wall suspension was freeze-dried. The purity of the preparations was confirmed by electron microscopy.

\section{Isolation of teichoic acid}

From cell walls. Wall preparations were stirred with $10 \%(\mathrm{w} / \mathrm{v})$ trichloroacetic acid solution (1.5 ml. to $50 \mathrm{mg}$. cell wall) for $16 \mathrm{hr}$. at $4^{\circ}$. Walls were removed by centrifugation and extracted again with trichloroacetic acid solution for $24 \mathrm{hr}$. at $4^{\circ}$. Cold ethanol ( 2 vol.) was added to the combined extracts which were then kept at $4^{\circ}$ for $24 \mathrm{hr}$. Precipitated teichoic acid was removed by centrifugation and reprecipitated from $10 \%(\mathrm{w} / \mathrm{v})$ trichloroacetic acid solution (about $5 \mathrm{ml}$.) by the addition of cold ethanol (1 vol.). After being kept at $4^{\circ}$ for $24 \mathrm{hr}$. the precipitate was collected in a centrifuge, washed with cold acetone, ethanol and ether, then dried in a desiccator (vacuum). More prolonged extraction of walls at $4^{\circ}$ yielded further small quantities of teichoic acid.

From cell contents. To the solution obtained after disruption of organisms and removal of walls by centrifuging was added cold $50 \%(\mathrm{w} / \mathrm{v})$ trichloroacetic acid solution to give a final concentration of $5 \%(w / v)$ trichloroacetic acid. After $16 \mathrm{hr}$. at $4^{\circ}$ the precipitate was removed by centrifuging and the clear solution was mixed with cold ethanol ( 2 vol.). The teichoic acid precipitated slowly at $4^{\circ}$; after 2-4 days it was collected and purified by the reprecipitation procedure described above for cell walls. 
Identification. Samples of teichoic acid from walls or cell contents were hydrolysed with $2 \mathrm{~N}$-hydrochloric acid for $3 \mathrm{hr}$. in sealed tubes at $100^{\circ}$. Hydrolysis products were identified by paper chromatography. Whatman no. 4 paper which had been washed in $2 \mathrm{~N}$-acetic acid, then water, was used with the solvent systems n-propanol + ammonia (sp.gr. 0.88) + water $(6+3+1)$ and $n$-butanol + ethanol + water + ammonia (sp.gr. $0 \cdot 88$; organic layer) $(40+10+49+1)$. Products were detected by the spray reagents used previously (Armstrong et al. 1958). All the appropriate hydrolysis products of glycerol or ribitol teichoic acids were detected and no other products were seen. The presence of alanine ester linkages was confirmed in all samples by treatment with ammonia, followed by paper chromatography of the resulting alanine amide in the propanol solvent system (Armstrong et al. 1958).

\section{RESULTS}

The distribution of the two types of teichoic acid in the walls and cell contents of a number of Lactobacillus spp. is given in Table 1 . The results are expressed qualitatively, and in each case refer to teichoic acid which had been isolated by the standard procedure and identified by chromatographic examination of hydrolysis products.

Table 1. Teichoic acid in walls and cell contents of Lactobacillus spp. in relation to serological groups

$\mathbf{R}=$ ribitol teichoic acid; $\mathbf{G}=$ glycerol teichoic acid; - = neither $\mathbf{R}$ nor $\mathbf{G}$ detected.

\begin{tabular}{|c|c|c|c|}
\hline \multirow[b]{2}{*}{ Organism } & \multicolumn{2}{|c|}{ Teichoic acid in } & \multirow{2}{*}{$\begin{array}{c}\text { Sero- } \\
\text { logical } \\
\text { group }\end{array}$} \\
\hline & Cells & Walls & \\
\hline L. arabinosus 17-5 & $\mathbf{G}$ & $\mathbf{R}$ & $\mathbf{D}$ \\
\hline L. plantarum NCIB 7220 & $\mathbf{G}$ & $\mathbf{R}$ & $\mathbf{D}$ \\
\hline L. brevis NCIB 8169 & $\mathbf{G}$ & $\mathbf{G}$ & $\mathbf{E}$ \\
\hline L. buchneri NCIB 8007 & G & $\mathbf{G}$ & $\mathbf{E}$ \\
\hline L. lactis NCIB 7278 & $\mathbf{G}$ & $\mathbf{G}$ & $\mathbf{E}$ \\
\hline L. bulgaricus NCIB 2889 & $\mathbf{G}$ & G & $\mathbf{A}$ \\
\hline L. helveticus NCIB 8025 & $\mathbf{G}$ & G & $\mathbf{A}$ \\
\hline L. plantarum NCIB 3254* & $\mathbf{G}$ & - & $\mathbf{B}$ \\
\hline L. casei ATCC 7469 & $\mathbf{G}$ & - & C \\
\hline L. bulgaricus NCIB 76* & $\mathbf{G}$ & - & $\mathbf{C}$ \\
\hline L. delbrueckii NCIB 8608* & $\mathbf{G}$ & - & c? \\
\hline L. fermenti NCIB 6991 & G & - & $\mathbf{F}$ \\
\hline L. delbrueckii NCIB & $\mathbf{G}$ & $\mathbf{G}$ & _- \\
\hline
\end{tabular}

* A fuller description of these organisms is given under Methods.

\section{DISCUSSION}

All the organisms examined in this survey contained a glycerol teichoic acid in the fraction corresponding to the cell protoplasm and structure beneath the wall. It is concluded that glycerol teichoic acids probably occur in the cells of all Lactobacillus spp.; moreover, this type has been found in the cell contents of a variety of Gram-positive bacteria studied in this laboratory (Armstrong et al. 1959). In only two or three cases was this material not detected, and it is possible that these failures occurred through the insensitivity of the analytical procedure, which 
depends upon actual isolation of precipitated material. Alternatively, the occasional occurrence of fat-soluble teichoic acids containing higher fatty ester residues cannot be discounted; such compounds would escape detection by the methods adopted in this work.

Although the function of teichoic acids is unknown, the widespread occurrence of the glycerol type in Gram-positive bacteria establishes their importance, and the chemical reactivity of their alanine ester residues suggests a metabolic function for these polymers. It has not yet been possible to determine their exact location within the cell, but if they are present in the protoplast membrane or other outer regions of the cell they may be visualized as partners to the wall teichoic acids, the whole system being well suited to such functions as the transport of ions.

Both ribitol and glycerol teichoic acids are found in walls, but in some cases neither type was detected even when large samples of wall were examined. This finding, and the absence of intracellular glycerol teichoic acid in those walls which contained the ribitol compound, indicated that little or no cross-contamination of wall and cell material occurred during the isolation procedure. Faint traces of ribitol derivatives were detected in the cell contents of those organisms which possessed ribitol teichoic acid in their walls. It is not known whether this arose through contamination. Exhaustive chemical studies have not yet been carried out on all samples of teichoic acid obtained from Lactobacillus, but it is possible that structural differences occur within the two general types found in these organisms.

Some correlation was observed between the nature of the teichoic acid in the walls and the metabolic properties of the organisms. It is now generally recognized that, although the classification of Lactobacillus spp. solely upon metabolic behaviour is unsatisfactory, they may be classified well by consideration of both metabolic and serological behaviour (Sharpe, 1955; Sharpe \& Wheater, 1957). Consequently, the serological groups of organisms studied in this work were compared with the teichoic acid of their walls. The serological groups listed in Table 1 are those described by Sharpe (1955) and Sharpe \& Wheater (1957). It is seen that the organisms of group D contained ribitol teichoic acid in their walls, whereas the walls of those in groups $\mathbf{E}$ and $\mathbf{A}$ contained a glycerol teichoic acid; groups B, C, and $\mathrm{F}$ contained no wall teichoic acid. These results suggest a relationship between the serological properties of Lactobacillus spp. and the teichoic acid in their walls. It is likely then that these substances themselves would participate in serological reactions. Authentic samples of teichoic acids have not been examined serologically, but a closely related bacterial glycerophosphate polymer was studied by McCarty (1959) who was able to prepare a specific antiserum to it. Clearly, the serological behaviour of Lactobacillus spp. would not be determined solely by the antigenic properties of their wall teichoic acids. Thus, groups B, C and F are serologically distinct groups, but their members contain no wall teichoic acids. Nevertheless, a knowledge of wall teichoic acids should be valuable in classifying Lactobacilli, and might be used occasionally to predict the serological grouping of new members.

Ikawa \& Snell (1960) detected teichoic acids in the walls of a number of Lactobacillus spp. Where identical strains have been used their results agree with those described here. However, they recorded the presence of a ribital teichoic acid in the walls of L. delbrueckii 730 (ACTC 9649) which is understood to be identical with the strain NCIB 8130 (Sharpe, 1959). We found a glycerol teichoic acid in walls of 
NCIB 8130 but no trace of a ribitol teichoic acid was detected. This small discrepancy is under investigation. Sharpe was unable to prepare an antiserum to this species but our observations would indicate its similarity to those of groups A or E.

We thank the Nuffield Foundation, the Medical Research Council and the Rockefeller Foundation for financial support, and Mr E. H. Boult of this Department for routine examination of walls under the electron microscope.

\section{REFERENCES}

Armstrong, J. J., Baddiley, J. \& Buchanan, J. G. (1960). Structure of the ribitol teichoic acid from the walls of Bacillus subtilis. Biochem. J. 76, 610.

Armstrong, J. J., Baddiley, J., Buchanan, J. G., Carss, B. \& Greenberg, G. R. (1958). Isolation and structure of ribitol phosphate derivatives (teichoic acids) from bacterial cell walls. J. chem. Soc. p. 4344 .

Armstrong, J. J., Baddiley, J., Buchanan, J. G., Davison, A. L., Kelemen, M. V. \& Neuraus, F. C. (1959). Composition of teichoic acids from a number of bacterial walls. Nature, Lond. 184, 247.

Barton-Wright, E. C. (1946). Practical Methods for the Microbiological Assay of Vitamin B Complex and Essential Amino Acids. London: Ashe Laboratories.

Irawa, M. \& SNELL, E. E. (1960). Cell wall composition of lactic acid bacteria. J. biol. Chem. 235, 1876.

MCCARTY, M. (1959). The occurrence of polyglycerophosphate as an antigenic component of various Gram-positive bacterial species. J. exp. Med. 109, 361.

Salton, M. R. J. \& Horne, R. W. (1851). Methods of preparation and some properties of cell walls. Biochim. Biophys. Acta, 7, 177.

ShARPE, M. E. (1955). A serological classification of Lactobacilli. J. gen. Microbiol. 12, 107.

Sharpe, M. E. (1957). A note on the source and identification of the strains of Lactobacilli submitted to chromatographic analysis. J. appl. Bact. $20,215$.

SHARPE, M. E. (1959). A note on the source and identification of the strains of thermophilic Lactobacilli submitted to chromatographic analysis. J. appl. Bact. 22, 325.

Sharpe, M. E. \& WheATER, D. M. (1957). Lactobacillus helveticus. J. gen. Microbiol. 16, 676. 